\title{
PRAKTYCZNE ASPEKTY DOCIEKAŃ PRZEDSTAWIONYCH W DZIELE „OSOBA I CZYN“
}

Książka Księdza Kardynała Wojtyły Osoba i czyn stanowi niewątpliwie wydarzenie w filozofii polskiej. Literatura antropologiczna wzbogaciła się o pozycję niezmiernie ważną ze względu na przedmiot i oryginalną, gdy chodzi o sposób ujęcia i to tak dalece, że zarówno w naszej dotychczasowej literaturze, a nawet w literaturze zagranicznej, tak przecież bogatej w książki o człowieku, nie znajdujemy jej odpowiedników.

\section{Autor Osoby i czynu}

- dokonał niezmiernie interesującej próby ujęcia filozofii człowieka nowocześnie, a zarazem $\mathrm{z}$ troską o pozostanie w ramach filozofii klasycznej i o zbudowanie zrozumiałej dla dzisiejszego człowieka (oczywiście tego, który chce się nieco intelektualnie potrudzić) metafizyki osoby ludzkiej;

- dał niezwykle głębokie spojrzenie na wiele zakamarków ,,ja” ludzkiego, zwłaszcza $\mathrm{w}$ aspekcie jego aktywności, a więc $\mathrm{w}$ punkcie najciekawszym i najbardziej istotnym - tam, gdzie osoba ludzka tworzy się właśnie poprzez czyn; doświadczenie czynu ludzkiego jest tu podstawą dla ujawnienia natury osoby;

- zgromadził wiele autentycznych doświadczeń oraz interesujących głębokich refleksji filozoficznych. Dzięki temu książka stanowi ogromnie cenną i niewyczerpaną wprost kopalnię przemyśleń o człowieku i materiału antropologicznego dla każdego, kto interesuje się sensem ludzkiego życia i kto chce te sprawy rozwiązywać w oparciu o rzetelną wiedzę i odpowiedzialne przemyślenia;

- dokonał ważnych innowacji metodologicznych, mianowicie próby połączenie fenomenologii i tomizmu, nie mającej precedensu w antropologicznej literaturze filozoficznej; wyniki tego „eksperymentu” oka- 
zały się bardzo szczęśliwe - tomizm wzbogacił się o świeżość doświadczeń, a fenomenologia wyszła poza krąg ujęć eidetycznych.

Są to wartości książki, które na pewno będą omawiane przez innych, toteż nie będę się nad nimi zatrzymywać, natomiast pragnęłabym zwrócić uwagę na fakt, który pozornie wydaje się paradoksalny — praktyczną rolę omawianej książki, aktualne i właśnie praktyczne znaczenie podjętej przez Księdza Kardynała problematyki i proponowanych rozwiązań, mimo że książka rzeczywiście posiada charakter teoretyczny. Jej aktualność i praktyczność ukazują się w całym kontekście dzisiejszej sytuacji kulturowej oraz przez jej ścisłe powiązania z etyką indywidualną i społeczną.

Zainteresowanie problematyką antropologiczną wielu współczesnych filozofów, ludzi zatroskanych o człowieka, współczesnego Kościoła nie jest przypadkowe. Spowodowała je wyjątkowo trudna i skomplikowana sytuacja, w jakiej znalazł się człowiek naszych czasów. Jego wielkie osiągnięcia, zwłaszcza w dziedzinie przekształcania świata graniczą z powszechnym obniżeniem moralności, wzrostem poczucia zagrożenia i osamotnienia. Nie bez realnych podstaw mówi się dziś o niebezpieczeństwie zagubienia istotnych wartości człowieka. Trudną sytuację pogłębia fakt, że współczesna nauka, a nawet cała kultura z wyraźną dominacją cywilizacji, w wielu przypadkach nie pozwala na zdobycie wszechstronnej, obiektywnej, dogłębnej a zarazem całościowej wiedzy o człowieku. Zafascynowanie nauką grozi również zapoznaniem transcendencji osoby ludzkiej w stosuku do świata natury i techniki. Tymczasem duchowe, polityczne i społeczne skazy cywilizacji, pogłębiając teoretyczne i praktyczne zagrożenia człowieka w jego najistotniejszych wymiarach, domagają się opracowania takiej teorii bytu ludzkiego, której wyjaśnienia wystarczyłyby do zbudowania podstaw światopoglądu, według którego człowiek mógłby organizować swoje postępowanie.

W dociekaniach antropologicznych nie chodzi więc tylko o zdobycie abstrakcyjnej, oderwanej od życia wiedzy o człowieku. Nie chodzi o poznanie teoretyczne dla niego samego. Prawda o osobie ludzkiej jest konieczna po to, by właściwie postępować i po ludzku żyć, by odpowiedzialnie wykonać człowiecze - osobiste i społeczne zadanie. Z wielu względów jest to potrzebniejsze i ważniejsze dziś niż kiedykolwiek. Nauka i technika wyposażyły bowiem człowieka w nieznane dotychczas możliwości przekształcania świata i życia ludzkiego, tworzenia nowych form bytowania społecznego. Masowa produkcja, masowa kultura i środki masowego przekazu oraz nieustannie wzrastający proces urbanizacji i socjalizacji powodują, że tak prawda o człowieku jak i jej wypaczenia natychmiast potęgują się i rozszerzają prawie w nieskończoność. Trzeba dobrze wiedzieć, kim człowiek jest, by odpowiednio pokierować już nie 
tylko losem osobistym, lecz także nieraz losem całej ludzkości, by wyznaczyć zgodnie $\mathrm{z}$ charakterem osoby ludzkiej perspektywy dalszych form egzystencji, a w niektórych przypadkach właściwie pokierować dalszym rozwojem ludzkości. Przynamniej w tej sprawie ma słuszność Teilhard de Chardin, gdy mówi, że losy dalszej ewolucji świata, a przede wszystkim losy człowieka, spoczywają obecnie w rękach ludzkich.

Potrzeba pogłębionej wiedzy o człowieku zarysowała się również w Kościele soborowym i posoborowym. Jeśli rozważania i dyskusje Ojców Soboru dotyczyły konfrontacji życia Kościoła i życia współczesnego świata i to dotyczyły spraw praktycznych, to podstawą konfrontacji i źródłem właściwych rozwiązań mogła stać się jedynie pełna prawda o człowieku, o jego wszechstronnych wymiarach. Jedne $\mathrm{z}$ nich były może zapoznane dotychczas przez Kościół, inne pomijane przez inne ideologie. Stąd zrodziła się konieczność ponownego sięgnięcia po uniwersalną, obiektywną prawdę o osobie ludzkiej, której wszechstronny i zharmonizowany rozwój jest przecież celem misji Kościoła i powinien być także troską społeczności świeckich.

Głęboką wymowę posiada fakt, że Autorem książki zawierającej filozoficzną teorię osoby ludzkiej jest uczestnik Soboru, współautor Konstytucji o obecności Kościoła w świecie współczesnym, filozof i teolog, myśliciel i człowiek czynnie zaangażowany w posługę duszpasterską. Fakt ten urasta do rangi symbolu wskazującego na organiczny związek, jaki zachodzi między teorią i praktyką. Napisanie książki ściśle filozoficznej, a więc teoretycznej, przez kogoś, kto tkwi w czynnym duszpasterstwie, świadczy o głębokim przekonaniu o potrzebie teorii dla praktyki, potrzebie filozofii dla zbudowania poglądu na świat — słowem - dla życia.

Praktyczny charakter dociekań i rozwiązań teoretycznych zawartych w książce przejawia się wprost poprzez jej powiązanie $z$ etyką. Autor rozpatruje przede wszystkim te problemy, które najbardziej powiązane są z ludzkim postępowaniem i rozwiązanie których może stanowić podstawę dla etyki. Rzeczywistość osoby jest fundamentem, z którego wyrasta czyn ludzki, będący przedmiotem zainteresowania etyki. $\mathrm{Z}$ konieczności przeto trzeba $\mathrm{w}$ etyce sięgać do teorii osoby, by można było mówić o etyce personalistycznej. Teoria osoby jest więc nieustannie przez etykę zakładana i inspiruje ją na zasadzie funkcji znajomości źródła, podstaw, przyczyny, sprawcy tego, co jest badane w etyce. Jak stwierdza sam Autor, potrzeby etyki zrodziły konieczność przyjrzenia się osobie jeszcze głębiej niż to się czyni w etyce, spojrzenia na nią dla niej samej, co jest potrzebne do tego, by ją ujrzeć właściwie i właściwie zinterpretować ludzkie działanie, zwłaszcza działanie moralne.

$\mathrm{Na}$ szczególną uwagę $\mathrm{w}$ omawianej książce zasługuje teoria uczestnictwa, która w nowym, całkowicie personalistycznym, kontekście uj- 
muje społeczny wymiar człowieka i jego działanie. To, co w dotychczasowej katolickiej społecznej nauce było rozważane jako dobro wspólne i zasada pomocniczości, a co może utraciło swą świeżość, dynamizm i atrakcyjność w zbyt abstrakcyjnych i jakby bezosobowych schematach myślowych, tu znalazło nowy, żywy wyraz, organicznie powiązany z naturą osobu ludzkiej, która jest „osobą wśród osób” i która tym bardziej staje się osobą, im bardziej poprzez działanie otwiera się na inne osoby i ich dobro.

W związku z prezentowaną przez Księdza Kardynała teorią uczestnictwa nasuwają się pewne dodatkowe, bardzo zresztą drobne wyjaśnienia, dokonane w oparciu o przemyślenia i doświadczenia tradycji filozoficznej $\mathrm{w}$ tej dziedzinie. O tyle wydają się one potrzebne, że historycznie teoria uczestnictwa (partycypacji) związana była z myślą Platona i rozwijana zwłaszcza w nurcie filozofii platońskiej i platonizującej i pewne sformułowania zawarte w książce, takie jak np. „zdolność uczestniczenia w samym człowieczeństwie każdego człowieka" (s. 322) mogą nasuwać skojarzenia z koncepcją partycypacji Platona. By ustrzec Czytelnika przed tym, warto może zwrócić uwagę na dwa podstawowe i różne znaczenia terminu uczestnictwo:

$1^{\circ} \mathrm{w}$ pierwszym znaczeniu - uczestniczyć znaczy ws półbyć, współdziałać, czyli bytować i działać z innymi, a więc być elementem jakiegoś, pod pewnym względem jednorodnego zbioru z tym, że między poszczególnymi elementami nie muszą zachodzić związki realne, np. przyczynowo-skutkowe;

$2^{\circ} \mathrm{w}$ drugim znaczeniu - uczestniczyć znaczy czerpać coś z czegoś, posiadać c zęść z jakiejś całości czy jakiejś pełni, przy czym całość i pełnię trzeba rozumieć w bardzo szerokim sensie. Uczestniczyć znaczy tu częściowo posiadać, czy częściowo przyjmować coś, co ktoś inny posiada w pełni. Według Platona rzeczy zmysłowe uczestniczyły w ideach, co znaczyło, że między nimi zachodzą relacje przyczynowo-wzorcze, a w realistycznej metafizyce mówi się o partycypacji bytu rozumiejąc przez to fakt, że wszystko, co istnieje, istnieje na mocy uczestnictwa w istnieniu Absolutu, który jest Pełnią Istnienia. Między Bogiem - Pełnią Istnienia, a bytami pozostałymi zachodzą relacje skutkowo-przyczynowe (sprawcze, wzorcze i celowe). Byty niekonieczne, przygodne, posiadają więc partycypatywny sposób istnienia.

W omawianej książce termin uczestnictwo brany jest zasadniczo w pierwszym znaczeniu, przy czym wyróżnia się dwie sytuacje, które jako typ uczestnictwa są jednej natury:

a) zdolność działania osoby ludzkiej z innymi osobami, przez co człowiek realizuje autentyczną wartość personalistyczną: spełnia czyn i spełnia w nim siebie (s. 296); 
b) uczestnictwo w samym człowieczeństwie innych ludzi, które stanowi rdzeń wszelkiego działania i bytowania „wspólnie z innymi” (s. 322).

Biorąc pod uwagę sytuację człowieka można wyróżnić kilka zasadniczych układów owego współbycia (od najbardziej słabego, luźnego do coraz mocniejszego i bardziej wiążącego):

1) na poziomie samego by to w a ni a - człowiek uczestniczy w bycie, to znaczy bytuje wraz z całą pozostałą rzeczywistością (jest jednym z bytów);

2) uczestniczy w tym, co stanowi bezpośrednie otoczenie człowieka; z elementami tego otoczenia może wchodzić w różnorodne związki np. skutkowo-przyczynowe;

3) na poziomie s pos obu istnienia, a więc na zasadzie tako źsamości bytowej - człowiek wspólistnieje z innymi bytami osobowymi, posiadającymi strukturę osobową, jest „osobą wśród osób”;

4) na poziomie natury gatunkow e j - człowiek współistnieje z innymi ludźmi czyli uczestniczy w człowieczeństwie innych, jest człowiekiem wśród ludzi;

5) na poziomie funkcji - człowiek współdziała z innymi tworząc grupy społeczne;

6) na poziomie relacji — indywidualnych różnego typu, np. przyjaźni, miłości - uczestniczy w życiu innych ludzi czyli w jakiś ściślejszy sposób jest związany z niektórymi osobami.

Mówiąc o uczestnictwie w człowieczeństwie innych Autor Osoby i czynu akcentuje takó̇samość bytową człowieka w stosunku do innych ludzi. Chociaż przez to nie stwierdza istnienia jakichkolwiek realnych związków między ludźmi, które stwierdza się np. wówczas, gdy mówi się o naszym uczestnictwie w istnieniu Boga, to jednak takożsamość bytowa osoby ludzkiej w stosunku do innych osób ludzkich wyznacza charakter relacji, które mogą zaistnieć między ludźmi. Fakt, że człowiek jest „osobą wśród osób" ma ogromne znaczenie praktyczne i to na wszystkich płaszczyznach. Stanowi o podstawowej równości i godności każdego człowieka, wyznacza jego prawa i obowiązki oraz charakter społecznego współdziałania, wzajemnych kontaktów międzyludzkich jak to w sposób ogromnie świeży i inspirujący — ukazuje Autor Osoby i czynu. W tym właśnie punkcie rozważań o osobie ludzkiej widać bardzo wyraźnie znaczenie właściwego odczytania prawdy o niej dla rozwiązań praktycznych. 